\title{
SALICYLATES AND THE ADRENAL CORTEX
}

\author{
BY \\ M. J. H. SMITH \\ Department of Chemical Pathology, King's College Hospital Medical School, London
}

The salicylates have been used in the symptomatic treatment of rheumatic disorders for over 50 years. They are capable of producing a striking change in the clinical picture of acute rheumatic fever and possess a smaller, but still definite, effect in rheumatoid arthritis. Their value as suppressive drugs appears to be concerned with alleviating the symptoms produced by the inflammatory processes which form a major part of the reaction of the body in rheumatic disease. The mechanism of this antiinflammatory action of salicylates is particularly obscure. In recent years, cortisone and related hormones have also been widely used as antirheumatic drugs. Their clinical effects in rheumatism are very similar to those of salicylates and it has been suggested that salicylate therapy is essentially corticosteroid therapy. More sophisticated versions of this statement have included mechanisms such as stimulation of the anterior pituitary and adrenal cortex and an accelerated rate of removal of circulating corticosteroids during salicylate treatment (Hailman, 1952; Roskam, 1956; Done, Ely, and Kelley, 1958). The purpose of the present article is to show that the available evidence, if examined critically, fails to provide convincing proof of the validity of the hypothesis that the therapeutic actions of salicylates in rheumatism are mediated by the adrenal cortex or its hormones.

If salicylates act through the adrenal cortex, they may do so in one or more of three ways:

(1) They stimulate the anterior pituitary to secrete adrenocorticotrophin, which in turn causes the adrenal cortex to produce corticosteroids.

(2) They have an adrenocorticotrophic action.

(3) They may reinforce the actions of the natural hormones by increasing the tissue uptake, blocking the destruction, or by increasing tissue sensitivity to adrenal corticosteroids. They may also possess direct corticosteroid-like effects on the tissues.
There is very adequate evidence that salicylates are capable of stimulating the so-called pituitary adrenal ${ }_{-}^{\infty}$ axis in experimental animals. Thus, it has repeat-i edly been shown that salicylates produce depletions ${ }_{\infty}$ of the adrenal content of ascorbic acid and cholesterolo (Hetzel and Hine, 1951; Van Cauwenberge, $1951 ;$ Cronheim, King, and Hyder, 1952), eosinopenia (Kelemen, Majoros, Iványi, and Kovács, 1950), and histological changes suggestive of adrenal hyper- 3 secretion (Robinson, 1951; Champy and Demay, $\mathbb{\varnothing}$ 1951; Tronchetti and Nello, 1952). More direct evidence of pituitary and adrenal stimulation hâsco been provided by the increased amounts of ACF (Eades and King, 1953) and of adrenal steroids found in the plasma (Van Cauwenberge, 1954; Good, Done, Ely, and Kelley, 1957) and urine (Laㅡㅡㅁ Barre and Hans, 1954) of animals treated with salicylates. Hypothalamic centres are also con-市 cerned because pretreatment with pentobarbital $\underset{\vec{\rho}}{\stackrel{2}{\rightleftarrows}}$ (Cronheim and Hyder, 1954) or previous destruction $\frac{0}{3}$ of the median eminence of the hypothalamus (George and Way, 1957) prevents the depletion of adrenal ascorbic acid produced by salicylates in normal animals.

However, the demonstration that salicylateso cause increased adrenal cortical activity in experi 3 . mental animals via the stimulation of hypothalamicos centres and the anterior pituitary does not mean that 3 their anti-rheumatic effects in man are producedo by the same mechanism. A number of objections may be raised against this interpretation. There iso no correlation between the effects of salicylate isomers on some of the experimental parameters of adrenal cortical function and their anti-rheumatic 0 properties. Thus, both the $m$ - and $p$-hydroxy $\frac{N}{\omega}$ benzoates, which are devoid of anti-rheumatico activity, cause significant depletions of adrenab ascorbic acid in rats (Smith, 1952a). Done, Ely, and Kelley (1956) have also reported that the metas compound causes elevated concentrations of cir-0 
culating 17-hydroxysteroids in the guinea-pig. A further criticism is that the animal experiments have been carried out with doses of 200 to $500 \mathrm{mg}$. $/ \mathrm{kg}$. body weight, and that these are far in excess of the usual therapeutic doses used in man. Most authors agree that there is no evidence of increased adrenal cortical activity in man following either short-term or long-term administration of therapeutic amounts of salicylate. Normal concentrations of circulating adrenal steroids, together with a normal or reduced urinary excretion of the steroids and their metabolites, have frequently been observed both in normal subjects and in patients with rheumatic fever or rheumatoid arthritis receiving salicylate therapy (Bayliss and Steinbeck, 1954; Smith, Gray, and Lunnon, 1954; Done, Ely, and Kelley, 1955; Kelley, Ely, Done, and Ainger, 1955; Peterson, Black, and Bunim, 1958). Increased plasma levels of circulating 17-hydroxysteroids have been reported to occur in children with salicylate intoxication (Done, Ely, and Kelley, 1954). This result is compatible with the animal work in that it must represent an adrenal response to stress of a toxic and non-specific nature.

The most pertinent objection to any hypothesis involving the participation of the pituitary adrenal axis in the anti-rheumatic actions of salicylates is provided by the reports that the drugs exert their anti-inflammatory effects in patients with Addison's disease (Thorn, 1958), in a rheumatoid arthritic patient whose adrenal function had been either markedly or completely suppressed (Peterson and others, 1958), and in adrenalectomized and hypophysectomized animals (Ungar, Damgaard, and Hummel, 1952). This data also serves to vitiate the suggestion that salicylates may have a direct adrenocorticotrophic action. Additional evidence against this mechanism is that hypophysectomy abolishes most of the responses suggestive of adrenal cortical stimulation, which are elicited by salicylates in normal animals ( $c f$. Done and others, 1958).

There remains the possibility that salicylates may either reinforce or mimic the actions of the natural adrenal steroids on the tissues. Done and others (1958) have stated that salicylates increase the rate of removal of exogenous hydrocortisone from the circulation and suggest that this effect may mask any concomitant adrenocortical stimulation. Peterson and others (1958) have failed to confirm that therapeutic doses of salicylate increase the rate of metabolism of either hydrocortisone or corticosterone in rheumatic fever patients. No significant changes in the miscible pool or rate of synthesis of hydrocortisone were observed in their experiments. It therefore appears unlikely that salicylates reinforce the actions of the natural hormones either by inhibiting their subsequent metabolism or by increasing their uptake by the tissues. Kelemen (1956) has shown that there is no synergism between the inhibitory effects of salicylates and hydrocortisone on experimentally induced oedema in the rat, which is against the suggestion that salicylate may increase the tissue response to adrenal steroids.

If salicylates either reinforce or mimic the actions of the natural hormones then they should produce very similar, if not identical, effects on metabolism. However, important differences have been described. It has been clearly shown that therapeutic doses of salicylate cause a marked and progressive increase of oxygen consumption in normal subjects and in patients with acute rheumatic fever and subacute rheumatism (Cochran, 1952; 1954). The relief of symptoms in the rheumatic patients appeared to be associated with the maintenance of the increased oxygen uptake. Hydrocortisone does not produce similar increases in the metabolic rate (Hetzel, Williams, and Lander, 1957). Salicylates have been found to reduce the hyperglycaemia and glycosuria of patients with diabetes mellitus and of experimentally diabetic animals, whereas cortisone and other adrenal steroids produce the reverse effects (Ingle, 1950; Smith, Meade, and Bornstein, 1952; Dibenedetto dell'Aquila and Angarano, 1954; Reid, Macdougall, and Andrews, 1957). The administration of cortisone causes liver glycogen deposition in adrenalectomized animals, and hyperglycaemia and glycosuria in normal rats, but these effects are inhibited by the concurrent administration of salicylates (Smith, 1952b). The different, opposite, and even antagonistic effects of salicylates and adrenal steroids cannot be reconciled with any mechanism which assumes that the two groups of drugs have the same fundamental actions on the peripheral tissues.

\section{Summary}

The possible mechanisms by which the therapeutic effects of salicylates in rheumatism could be mediated by the adrenal cortex and its hormones are discussed. It is concluded that the administration of large amounts of salicylates to experimental animals and to man may produce a stimulation of the pituitary-adrenal axis leading to an increased secretion of adrenal steroids. However, this stimulation represents a pituitary-adrenal response to stress of a toxic and non-specific nature, and is not concerned as a mediator in the antiinflammatory effects of therapeutic doses of salicylates. The available experimental evidence does not support the view that salicylates may either mimic or reinforce the actions of the natural 
adrenal hormones on the tissues. The similar clinical effects of salicylates and adrenal steroids in rheumatic diseases must therefore be produced by different mechanisms.

\section{REFERENCES}

Bayliss, R. I. S., and Steinbeck. A. W. (1954). Lancet, 1, 1010. Champy, C.. and Demay, M. (1951). J. Amer. med. Ass., 145. 1365. Cochran, J. B. (1952). Brit. med. J., 2, 964.

Cochran, (1954). Ibid., 1, 733.

Cronheim, G., and Hyder, N. (1954). Proc. Soc. exp. Biol. (N.Y.),

86. 409.
King. J. S., and Hyder. N. (1952). Ibid.. 80. 51.

Dibenedetto dell Aquila, M.. and Angarano, D. (1954). Folia endocr. (Pisa), 7, 5 .

Done, A. K., Ely, R. S., and Kelley, V. C. (1954). J. Pediat., 44, 153.

(1955). Metabolism, 4, 129

(1956). Proc. Soc exp. Biol. (N.Y.), 93.294.

(1956). Proc. Soc. exp. Biol

Eades, C. H.. and King. J. S. (1953). Endocrinologv, 52, 594.

Eades, C. H., and King. J. S. (1953). Endocrinology, 52, 594
George, R.. and Way. E. L. (1957). J. Pharmacol., 119, 310.

Good, T. A., Done, A. K., Ely, R. S., and Kelley, V. C. (1957). Metabolism, 6, 346

Hailman, H. F. (1952). J. clin. Endocr., 12, 454.

Hetzel, B. S. and Hine. D. C. (1951). Lancet, 2, 94

Hetzel, B.liams, R., and Lander. H. (1957). Aust. Ann. Med., 6, 218

Ingle, D. J. (1950). Proc. Soc. exp. Biol. (N.Y.). 75, 673.

Kelemen, E. (1956). Acta med. Hungarica, 9 , 125.

-, Majoros, M.. Iványi. J., and Kovács, K (1950). Experientia (Basel), 6, 435.

Kelley, V. C., Ely, R. S., Done, A. K., and Ainger. L. E. (1955). Amer. J. Med., 18. 20.

La Barre, J., and Hans, M. J. (1954). C.R. Soc. Biol. (Paris) 148, 723 .

Peterson, R. E.. Black, R. L.. and Bunim, J. J. (1958). Arthr. and Rheum., 1, 29

Reid, J.. Macdougall, A. I., and Andrews, M. M. (1957). Brit. med. J.. 2, 1071

Robinson. F. B. (1951). Ibid.. 1, 300

Roskam, J. (1956). Bull. Acad Suisse sci. Med., 12, 120.

Smith. M. J. H. (1952a). Lancet, 1.991.

(1952b). Biochem. J., 52, 649.

Meade, B. W., and Bornstein, J. (1952). Biochem. J., 51, 18.

Thorn, G. (1958). Personal communication, quoted by Peterson, Black, and Bunim (1958)

Tronchetti, F., and Nello, P. R. (1952). Folia endocr. (Pisa), 5, 365.

Ungar G., Damgaard. E., and Hummel, F. P. (1952). Amer. J. Physiol., 171, 545.

Van Cauwenberge $H$ (1951). Lancet, 2, 374.

- (1954). C.R. Soc. Biol. (Paris), 148, 1297.

\section{Salicylates et l'écorce surrénale}

RÉSUMÉ

On considère les mécanismes possibles par lesquelş l'écorce surrénale et ses hormones pourraient intervenir pour produire l'effet thérapeutique des salicylates dans le rhumatisme. On conclut que l'administration de doses fortes de salicylates aux animaux expérimentaux et à l'homme peut stimuler l'axe pituito-surrénal aboutis sant à la secrétion augmentée des stéroïdes surrénaux Toutefois, cette stimulation représente une réaction pituito-surrénale de nature toxique et non-spécifique aน stress, et n'est pas en cause comme médiatrice dans lešs effets anti-inflammatoires des doses thérapeutiques dessalicylates. Les données expérimentales existantes ne viennent pas à l'appui de la théorie que les salicylateš soient capables d'imiter ou de renforcer les actions des్ hormones surrénales naturelles sur les tissus. Le effets cliniques similaires des salicylates et des stéroïde surrénaux dans les maladies rhumatismales se pro duiraient donc par des mécanismes différents.

\section{Salicilatos y corteza suprarrenal}

\section{Sumario}

స్

Se discuten los mecanismos posibles por los cuales la corteza suprarrenal y sus hormonas pudieran mediar para producir los efectos terapéuticos de los salicilatos en el reumatismo. Se concluye que la administración dळ dosis fuertes de salicilatos al animal experimental y aథ hombre puede estimular el eje pituito-suprarrenals conduciendo a la secreción aumentada de esteroideक suprarrenales. Sin embargo, esta estimulación repre= senta una reacción pituito-suprarrenal al stress $\mathcal{Z} \mathrm{deo}$ naturaleza tóxica y noespecífica, sin comprometêss como mediadora en los efectos anti-inflamatorios de dosis terapéuticas de salicilatos. Los datos exper mentales existentes no vienen en apoyo de la teoría segtus la cual los salicilatos puedan imitar o reforzar las acciones de las hormonas suprarrenales naturales sobre los tejidos. Los efectos clínicos similares de los salp cilatos y de los esteroides suprarrenales en las enfer $\mathbb{Q}$ medades reumáticas se producirían, pués, por mecanis mos diferentes. 